\title{
Effect of Attractiveness of Protein and Glucose Baits in Estuarine Ant Communities in Southern Brazil
}

\author{
Carrasco D*1 and Bolico C F R S ${ }^{2}$ \\ ${ }^{1}$ Laboratório de Genética, Instituto de Ciências Biológicas, Brasil \\ ${ }^{2}$ EEEM Carlos Lorea Pinto, Secretaria Estadual de Educação do Estado do Rio Grande do Sul, Brasil
}

Submission: August 03, 2020; Published: September 10, 2020

Corresponding author: Carrasco D, Laboratório de Genética, Instituto de Ciências Biológicas, Universidade Federal do Rio Grande - FURG Av Itália, Km 8, s/n. Bairro Carreiros CEP.: 96203-000, Rio Grande - RS, Brasil

\section{Abstract}

Salt marshes are intertidal coastal ecosystems flooded irregularly by salt water. Ants (Hymenoptera: Formicidae) are important predators of invertebrates in most ecosystems and are prominent herbivores in many Neotropical communities, including salt marshes. The aims of this study are to quantify the feeding preference of ant communities and to estimate the diversity and similarity along the Lagoa dos Patos Estuary salt marshes. We chose three salt marshes in Lagoa dos Patos Estuary along a salinity gradient: Low Estuary $\left(32^{\circ} 10^{\prime} 65^{\prime \prime} \mathrm{S}\right.$; $\left.052^{\circ} 08^{\prime} 52^{\prime \prime} \mathrm{W}\right)$, Middle Estuary ( $\left.32^{\circ} 02^{\prime} 01^{\prime \prime} \mathrm{S} ; 052^{\circ} 10^{\prime} 45^{\prime \prime} \mathrm{W}\right)$ and Upper Estuary ( $\left.31^{\circ} 53^{\prime} 33^{\prime \prime} \mathrm{S} ; 052^{\circ} 14^{\prime} 33^{\prime \prime} \mathrm{W}\right)$. We used transections with protein and glucose baits. We found 25 ant species. Most of them was attracted by the two types of bait, being considered omnivores. We recorded the largest catch at the closest point to the sea, the Low Estuary, on both baits. We did the smallest catches in the Upper Estuary $(\mathrm{K}=5.204 ; \mathrm{df}=2 ; \mathrm{P}<0.05)$. We found that Low and Middle Estuary showed proximate values of the quotient (Protein/Glucose +1 ), indicating that ant's eating habits were the same in these portions of Lagoa dos Patos Estuary. However, there was a tendency for ants preferring the Glucose baits in the Upper Estuary.

Kewords: Feeding preference; Formicidae; Salinity gradient; Salt marshes.

\section{Introduction}

Salt marshes are intertidal coastal ecosystems flooded irregularly by salt water, occupied by herbaceous vegetation and small shrubs [1]. These ecosystems occur in protected areas of estuaries, bays, and lagoons in tropical and subtropical regions. They are considered highly productive organic matter ecosystems, offering shelter and habitat for various animal species [2]. High productivity in salt marshes creates an attractive resource base for terrestrial consumers, but tidal inundation creates a harsh environment $[3,4]$. The inhabitant organisms exhibit adaptations, including synchronism of activity with the tidal cycles, great mobility to escape the floods, and physiological tolerance to submersion [3,5,6]. Ants (Hymenoptera: Formicidae) are the world's most successful group of eusocial insects $[7,8]$. They are important predators of invertebrates in most ecosystems and are also prominent herbivores in many Neotropical communities, including salt marshes [9-11].

Formicidae is a great model for food web studies [12,13]. Ants are common inhabitants in terrestrial ecosystems $[7,14]$. Moreover, ants are tropically diverse, with herbivores that feed on sugary exudates common in food webs with abundant vegetation, such as forest canopies and grasslands, and predators that feed on the consumers of decomposer microbes, common in litter food webs [15-17]. The aims of this study are (1) to quantify the feeding preference of ant communities and (2) to estimate the diversity and similarity of ant community along the Lagoa dos Patos Estuary salt marshes.

\section{Materials and Methods}

We chose three salt marshes in Lagoa dos Patos Estuary along a salinity gradient: Low Estuary (32¹0'65"S; $052^{\circ} 08^{\prime} 52^{\prime \prime} \mathrm{W}$ ), highly influenced by salinity, $2 \mathrm{~km}$ from Atlantic Ocean; Middle Estuary ( $\left.32^{\circ} 02^{\prime} 01^{\prime \prime} \mathrm{S} ; 052^{\circ} 10^{\prime} 45^{\prime \prime} \mathrm{W}\right)$, that receives fresh and salt water input, constituting a brackish environment, $17 \mathrm{~km}$ from the

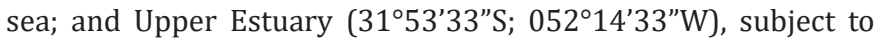
major influence of freshwater, $54 \mathrm{~km}$ from the sea. The dominant plant species are Spartina densiflora, Spartina alterniflora, Scirpus olneyi, Scirpus maritimus, Juncus krausii and the shrub Myrsine parvifolia [18]. We sampled ant communities in nine points (three 
at each collection station), during a year, totalizing 108 samples per bait. We used transections with alternate baits. Protein baits were sardine baits, simulating the most common kind of protein in this environment. Glucose baits were honey baits. The traps were exposed for 60 minutes [19].

The analysis of ant abundances data was based on the species occurrence in samples, which is recommended for quantifying abundances of social insects $[20,21]$. We recorded the ants by the kind of bait. Censuses were repeated for each of three stations. We transformed data in a logarithm scale $\left(\log _{10} x+1\right)$. We identified the ants according to Fernández [22] and we sent the specimens to Museu de Zoologia da Universidade de São Paulo (MZ- USP) to deposit in the scientific collection of MZ - USP. The specialists of MZ-USP also confirmed the ant's identification. We considered only the species that occurred in the three areas to perform the analysis of food preference. We chose the quotient Protein/ Glucose +1 (the denominator cannot be zero) to perform the statistical analysis [17]. A Tukey's HSD test following an analysis of variance [23] was used to evaluate the null hypothesis of no differences among sites in the dissimilarity of assemblages along the gradient of Estuary. The similarity between areas was verified through the Jaccard and Morisita indexes [24].

\section{Results}

We found 25 ant species (12 genera, 4 subfamilies). Most of them was attracted by the two types of bait, being considered omnivores. Four species were exclusive of Low Estuary and one was exclusive of Middle Estuary. Two species of Nylanderia were attracted only by protein bait (Table 1 ). The values of ant occurrence in each collection station by bait attraction are shown in Figure 1 in logarithmic scale. We highlight the presence of seven species of the genus Pheidole in which the species number 4, 5, 6 and 7 were more associated to protein baits. Solenopsis invicta, Wasmannia auropunctata, Camponotus punctulatus, Linepithema humile and Pseudomyrmex phillophylus were representative along the salt marshes' Estuary. We recorded the largest catch at the closest point to the sea, the Low Estuary, on both baits. We did the smallest catches in the Upper Estuary, about $50 \mathrm{~km}$ from the sea $(\mathrm{K}=5.204 ; \mathrm{df}=2 ; \mathrm{P}<0.05)$.

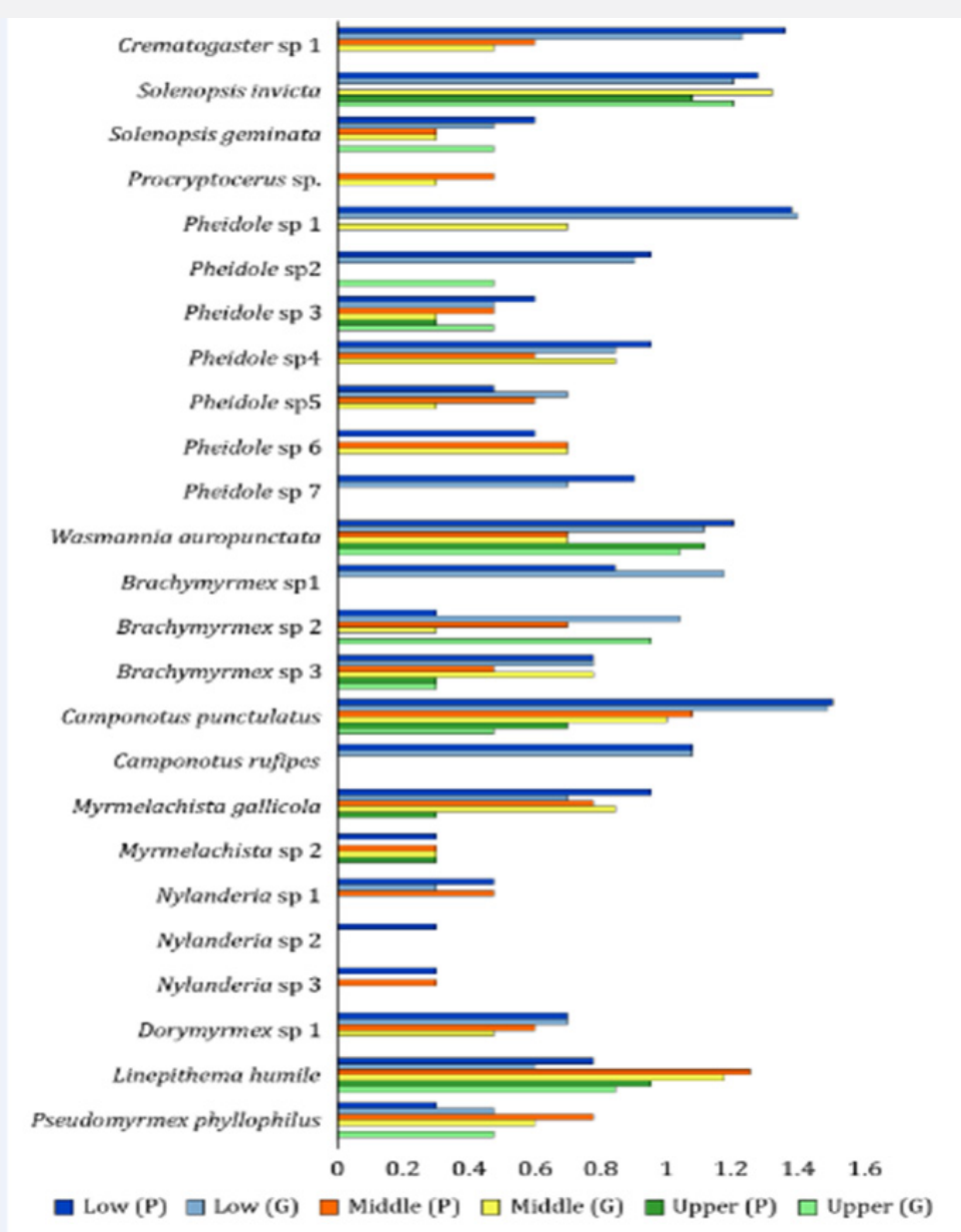

Figure 1: Ant visitation to Protein $(P)$ and Glucose $(G)$ baits in three points in Lagoa dos Patos Estuary: Low, Middle and Upper Estuary - in reference to the distance from the sea: $2 \mathrm{~km}, 17 \mathrm{~km}$ and $54 \mathrm{~km}$, respectively. The frequency is the number of samples in which the species occurred. 


\section{Oceanography \& Fisheries Open access Journal}

Table 1: Three ant communities: Low Estuary, Middle Estuary and Upper Estuary sampled for Protein $(P)$ and Glucose $(G)$ use.

\begin{tabular}{|c|c|c|c|}
\hline Ant species & Low & Middle & Upper \\
\hline \multicolumn{4}{|l|}{ MYRMICINAE } \\
\hline Crematogaster sp 1 & $\mathrm{P}, \mathrm{G}$ & $\mathrm{P}, \mathrm{G}$ & \\
\hline Solenopsis invicta & $\mathrm{P}, \mathrm{G}$ & G & $\mathrm{P}, \mathrm{G}$ \\
\hline Solenopsis geminata & $P, G$ & $P, G$ & G \\
\hline Procryptocerus sp. & & $\mathrm{P}, \mathrm{G}$ & \\
\hline Pheidole sp1 & $\mathrm{P}, \mathrm{G}$ & G & \\
\hline Pheidole sp 2 & $\mathrm{P}, \mathrm{G}$ & & G \\
\hline Pheidole sp 3 & $\mathrm{P}, \mathrm{G}$ & $\mathrm{P}, \mathrm{G}$ & $\mathrm{P}, \mathrm{G}$ \\
\hline Pheidole sp 4 & $\mathrm{P}, \mathrm{G}$ & $\mathrm{P}, \mathrm{G}$ & \\
\hline Pheidole sp 5 & $\mathrm{P}, \mathrm{G}$ & $\mathrm{P}, \mathrm{G}$ & \\
\hline Pheidole sp 6 & $\mathrm{P}$ & $\mathrm{P}, \mathrm{G}$ & \\
\hline Pheidole sp 7 & $\mathrm{P}, \mathrm{G}$ & & \\
\hline Wasmannia auropunctata & $\mathrm{P}, \mathrm{G}$ & $\mathrm{P}, \mathrm{G}$ & $\mathrm{P}, \mathrm{G}$ \\
\hline \multicolumn{4}{|l|}{ FORMICINAE } \\
\hline Brachymyrmex sp 1 & $\mathrm{P}, \mathrm{G}$ & & \\
\hline Brachymyrmex sp 2 & $\mathrm{P}, \mathrm{G}$ & $\mathrm{P}, \mathrm{G}$ & G \\
\hline Brachymyrmex sp 3 & $\mathrm{P}, \mathrm{G}$ & $\mathrm{P}, \mathrm{G}$ & $\mathrm{P}, \mathrm{G}$ \\
\hline Camponotus punctulatus & $\mathrm{P}, \mathrm{G}$ & $\mathrm{P}, \mathrm{G}$ & $\mathrm{P}, \mathrm{G}$ \\
\hline Camponotus rufipes & $\mathrm{P}, \mathrm{G}$ & & \\
\hline Myrmelachista gallicola & $\mathrm{P}, \mathrm{G}$ & $\mathrm{P}, \mathrm{G}$ & $\mathrm{P}$ \\
\hline Myrmelachista sp 2 & $P$ & $P, G$ & $\mathrm{P}$ \\
\hline Nylanderia sp 1 & $\mathrm{P}, \mathrm{G}$ & $\mathrm{P}$ & \\
\hline Nylanderia sp 2 & $\mathrm{P}$ & & \\
\hline Nylanderia sp 3 & $P$ & $\mathrm{P}$ & \\
\hline \multicolumn{4}{|l|}{ DOLICHODERINAE } \\
\hline Dorymyrmex sp 1 & $\mathrm{P}, \mathrm{G}$ & $P, G$ & \\
\hline Linepithema humile & $\mathrm{P}, \mathrm{G}$ & $\mathrm{P}, \mathrm{G}$ & $\mathrm{P}, \mathrm{G}$ \\
\hline \multicolumn{4}{|l|}{ PSEUDOMYRMICINAE } \\
\hline Pseudomyrmex phyllophilus & $\mathrm{P}, \mathrm{G}$ & $P, G$ & G \\
\hline
\end{tabular}

We found that Low and Middle Estuary showed proximate values of quotient, indicating that ant's eating habits were the same in these portions of Lagoa dos Patos Estuary. However, there was a tendency for ants preferring the Glucose baits in the Upper Estuary, decreasing the quotient, being significantly lower than the other sampled sites (Figure 2). The richness of ant species showed a significant interaction with the marine gradient (Low Estuary = 24; Middle Estuary = 20; Upper Estuary = 12 species; $\mathrm{K}$ $=7.155 ; \mathrm{df}=2 ; \mathrm{P}<0.05)$. The richness of ants associated with salt marshes has gradually decreased as we moved away from marine influence. As consequence, the cluster analysis indicated that Upper Estuary is the dissimilar area (Figure 3, Table 2).
Table 2: Morisita's distance index in three sampling sites in the Lagoa dos Patos, Brazil, estuarine zone, considering ant communities.

\begin{tabular}{|c|c|c|c|}
\hline & Low & Middle & Upper \\
\hline Low & 1 & & \\
\hline Middle & 0.66 & 1 & \\
\hline Upper & 0.48 & 0.61 & 1 \\
\hline
\end{tabular}




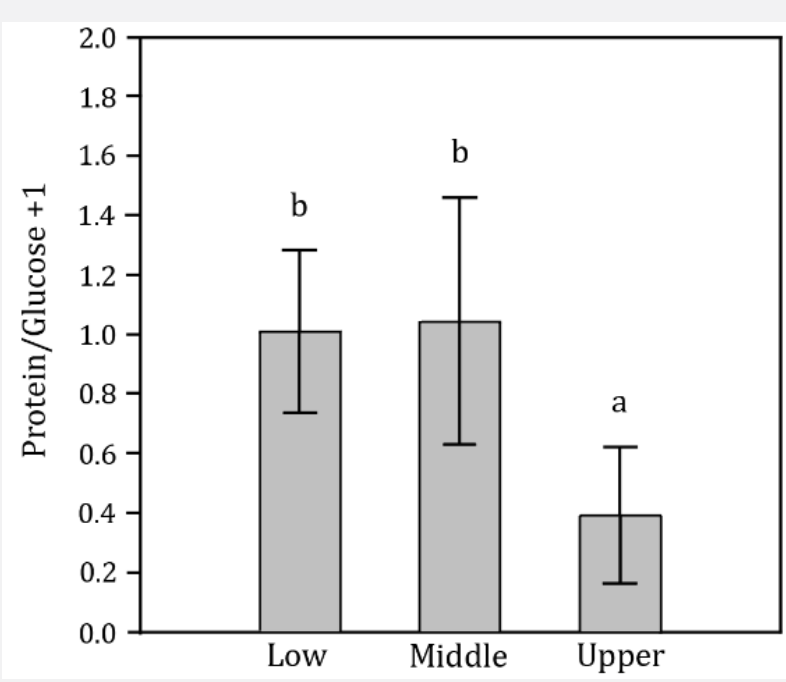

Figure 2: The ratio of Protein baits and Glucose baits is compared among three ant communities: Low Estuary, Middle Estuary and High Estuary. Letters above bars signify significant difference using Tukey's HSD with $\mathrm{P}<0.05$.

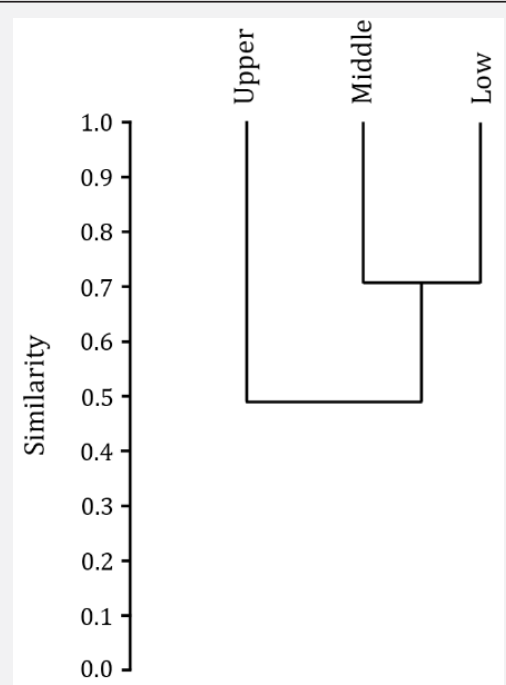

Figure 3: Cluster analysis based on the ant community's diversity matrix in three estuarine zones, using Jaccard Similarity Index (UPGMA; Cophenetic correlation $=0.967$ ).

\section{Discussion}

Pheidole was the genus with the major number of species collected. They can play an important role in the Lagoa dos Patos salt marshes because many of these ants are predators and diggers [25], helping in the remobilization of fine sediments and in the plant root oxygenation. Another key species could be Camponotus punctulatus. It forms colonies with an association of macroinvertebrates, fungiand bacteriaacting on the decomposition of organic matter [26,27]. The presence of Solenopsis invicta, Wasmannia auropunctata, and Linepithema humile may have influenced locally the diversity of ants. In common, these species are aggressive and form large colonies [28-30]. We have not tested the effect of competition, but previous studies have shown that mainly Solenopsis invicta is a better forager and it displace less efficient species [31,32]. Pseudomyrmex phillophilus is associated with small shrubs or trees present in the study area, since species of Pseudomyrmex are usually arboreal [33].

We found an anomalous behavior for Nylanderia species. According to Cook et al. [34], this genus prefers diets rich in carbohydrates. Therefore, they would be expected to select the glucose bait. In salt marshes, many arthropods are linked to decomposition of carcasses, including ants [35]. Small carcasses, such as cockroaches, crabs, terrestrial isopods, are more available resources than the salt marshes own plants, because most of them have a physical structure and secondary chemistry of unpalatable plants and produce an unpalatable litter too [36-38]. 
So, we expected a large assemblage of carnivorous ants, with a low incidence of capture in the glucose baits. Within the limits of reasonable statistical power ( 3 sites, 3 substations, 108 samples), we showed that two communities (Low and Middle Estuary) consistently increased protein use relative to glucose, but one community do not (Upper Estuary).

Formicidae is a group of eusocial organisms that have a high demand for carbohydrates [39]. Ants on protein-rich, carbohydrate poor foods fulfill their carbohydrate requirements collecting large quantities of this food. However, these colonies experienced significantly elevated worker mortality $[40,41]$, possibly because of "food stress" [42]. This explains why most species were found in both kind of bait. Glucose would serve to balance the demand for carbohydrates, which can be a limiting factor in salt marshes. In the Upper Estuary perhaps the resource could be more limited, which would explain the greater attractiveness of glucose baits compared to Middle and Low Estuary.

Analyzing the richness, we found that the major richness of ants was proportional to the marine influence in the Lagoa dos Patos Estuary. Kaspari et al., [17] also found that the species richness of ants increased with increasing salinity, in contrast with the negative effect of salinity on ants occurring in other coastal environments. This apparently contradictory result could arise, in part, because of the salinity gradient could operate as an environmental filter, allowing different ant species along the gradient depending on their tolerance to salt stress [43]. In fact, plant diversity also increases with salinity in these marshes [44], which also indicates an increase in niche availability for ants [44]. Low and Middle Estuary showed exclusive species, Upper Estuary did not, which could confirm this tendency.

However, we propose studies focusing on taxonomic patterns (subfamilies, tribes, and genera) and ant autecology to understand better the mechanisms of foraging and diversity along the estuarine gradients and take definite conclusions.

\section{References}

1. Costa C S B (1997) Plantas de marismas e terras alagáveis. In: Seeliger U, Odebrecht C, J P Castello (eds.). Os ecossistemas costeiro e marinho do extremo sul do Brasil. Editora Ecoscientia, Rio Grande, US, Pp. 326.

2. Marangoni J C, C S B Costa (2006) Variação temporal da extensão das marismas do estuário da Lagoa dos Patos (RS): Causas antrópicas e processos naturais. In: Anais do I Simpósio Biomas Costeiros e Marinhos. Salvador (BA): CBCN - Centro Brasileiro para Conservação da Natureza e Desenvolvimento Sustentável.

3. Lalli C M, R T Parsons (1993) Biological oceanography: an introduction. ( $2^{\text {nd }} e d n$.) The Open University Pp. 337.

4. Childress E S, A A Koning (2013) Polydomous Crematogaster pilosa (Hymenoptera: Formicidae) colonies prefer highly connected habitats in a tidal salt marsh. Florida Entomologist 96(1): 235-237.

5. Cheng L (1976) Marine Insects. Amsterdam: North-Holland, Netherlands Pp. 581.
6. Pétillon J, Montaigne W, D Renault (2009) Hypoxic coma as a strategy to survive inundation in a saltmarsh inhabiting spider. Biology Letters 5: 442-445.

7. Hölldobler B, E O Wilson (1990) The Ants. The Belknap Press of Harvard University Press, Massachusetts, US, Pp. 732.

8. Brady S G, Schultz T R, Fisher B L, P S Ward (2006) Evaluating alternative hypotheses for the early evolution and diversification of ants. Proceedings of the National Academy of Sciences 103: 1817218177.

9. Brown W L (2000) Diversity of ants. In: Agosti D, Majer J D, Alonso L E, T R Schultz (eds.). Ants, Standard Methods for Measuring and Monitoring Biodiversity. Smithsonian Institution Press, Washington, US, Pp. 280.

10. Piovia-Scott J, Spiller D A, T W Schoener (2011) Effects of experimental seaweed deposition on lizard and ant predation in an island food web. Science 331: 461-463.

11. Bolico C F, Oliveira E A, Gantes M L, Dumont L F C, Carrasco D S, et al. (2012) Mirmecofauna (Hymenoptera, Formicidae) de duas marismas do Estuário da Lagoa dos Patos, RS: diversidade, flutuação de abundância e similaridade como indicadores de conservação. Entomobrasilis 5 (1): 11-20.

12. Chen B, D H Wise (1999) Bottom-up limitation of predaceous arthropods in a detritus-basec terrestrial food web. Ecology 80: 761772.

13. Feldhaar H, Gebauer G, N Blüthgen (2010) Stable isotopes: past and future in exposing secrets of ant nutrition (Hymenoptera: Formicidae). Myrmecological News 13: 3-13.

14. Yanoviak S P, M Kaspari (2000) Community structure and the habitat templet: ants in the tropical forest canopy and litter. Oikos 89: 256266.

15. Davidson D W, Cook S C, Snelling R R, T H Chua (2003) Explaining the abundance of ants in lowland tropical rainforest canopies. Science 300: 969-972.

16. Kaspari M (2004) Using the metabolic theory of ecology to predict global patterns of abundance. Ecology 85: 1800-1802.

17. Kaspari M, Yanoviak S P, R Dudley (2008) On the biogeography of salt limitation: a study of ant communities. Proceedings of the National Academy of Sciences 105: 17848-17851.

18. Costa C S B, Marangoni J C, A M G Azevedo (2003) Plant zonation in irregularly flooded salt marshes: relative importance of stress tolerance and biological interactions. Journal of Ecology 91(6): 951965.

19. Freitas A V L, Francini R B, K S Brown (2003) Insetos como indicadores ambientais. In: Cullen L, Valladares-Pádua C, R Rudran (eds.). Métodos de estudos em biologia da conservação e manejo da vida silvestre. Editora da UFPR, Curitiba, Brasil, Pp. 665.

20. Diaz-Castelazo C, Rico-Gray V, Oliveira P S, M. Cuautle (2004) Extrafloral nectary-mediated ant-plant interactions in the coastal vegetation of Veracruz, Mexico: richness, occurrence, seasonality, and ant foraging patterns. Ecoscience 11: 472-481.

21. Gotelli N J, Ellison A M, Dunn R R, N J Sanders (2011) Counting ants (Hymenoptera: Formicidae) biodiversity sampling and statistical analysis for myrmecologists. Myrmecological News 15: 13-19.

22. Fernandez F (2003) Introducción a las hormigas de la región Neotropical. Bogotá, Colômbia, Instituto de Investigación de Recursos Biológicos Alexander von Humboldt, Pp. 411. 
23. Zar J H (1999) (4 $4^{\text {th }}$ edn.). Biostatistical analysis, Prentice-Hall, New York, US, Pp.929.

24. Kunin W E (1995) Towards an asymmetric index of community similarity. Oikos 73: 442-443.

25. Forti L C, Camargo R S, Fujihara R T, J F S Lopes (2007) The nest architecture of the ant, Pheidole oxyops Forel, 1908 (Hymenoptera: Formicidae). Insect Science 14: 437-442.

26. Folgarait P J, Gorosito N, Pizzio R, Rossi J P, J Fernandez (2007) Camponotus punctulatus ant's demography: a temporal study across land-use types and spatial scales. Insectes Sociaux 54: 42-52.

27. Paris C I, Polo M G, Garbagnoli C, Martínez P, Ferré G S, et al. (2008) Litter decomposition and soil organisms within and outside of Camponotus punctulatus nests in sown pasture in Northeastern Argentina. Applied Soil Ecology 40(2): 271-282.

28. Human K G, D M Gordon (1996) Exploitation and interference competition between the invasive Argentine ant, Linepithema humile, and native ant species. Oecologia 105: 405-412.

29. Le Breton J, Delabie H C J, Chazeau J, Dejean A, H Jourdan (2004) Journal of Insect Behavior 17: 263- 271.

30. Peterson A T, Y Nakazawa (2008) Environmental data sets matter in ecological niche modelling: an example with Solenopsis invicta and Solenopsis richteri. Global Ecology and Biogeography 17: 135-144.

31. Jones S R, S A Phillips (1990) Resource collecting abilities of Solenopsis invicta (Hymenoptera: Formicidae) compared with those of three sympatric Texas ants. Southwestern Naturalist 35: 416-422.

32. Ascunce M S, Yang C C, Oakey J, Calcaterra L, Wu W J, et al. (2011) Global invasion history of the fire ant Solenopsis invicta. Science 331 1066-1068.

33. Chomicki G, Ward P S, S S Renner (2015) Macroevolutionary assembly of ant/plant symbioses: Pseudomyrmex ants and their ant-housing plants in the Neotropics. Proceedings of the Royal Society B: Biological Sciences 282: 1-9.
34. Cook S C, Wynalda R A, Gold R E, S T Behmer (2011) Macronutrient regulation in the Rasberry crazy ant (Nylanderia sp. nr. pubens) Insectes Sociaux 59: 93-100.

35. Richards S L, Connely C R, Day J F, Hope T, R Ortiz (2015) Arthropods associated with carrion in a salt marsh habitat in southeastern Florida. Florida Entomologist 98: 613-619.

36. Grime J P, Cornelissen J H C, Thompson K, J G Hodgson (1996) Evidence of a causal connection between anti-herbivore defense and the decomposition rate of leaves. Oikos 77: 489-494.

37. Cornelissen J H C, Quested H M, Gwynn-Jones D, Van Logtestijn R S P, De Beus M A H, et al. (2004) Leaf digestibility and litter decomposability are related in a wide range of subarctic plant species and types. Functional Ecology 18: 779-786.

38. Pennings S C, Zimmer M, Dias N, Sprung M, Davé N, et al. (2007) Latitudinal variation in plant-herbivore interactions in European salt marshes. Oikos 116: 543-549.

39. Kay A D, Bruning A J, van Alst A, Abrahamson T T, Hughes W O H, et al. (2013) A carbohydrate-rich diet increases social immunity in ants. Proceedings of the Royal Society B: Biological Sciences 281: 2374.

40. Cook S C, Eubanks M D, Gold R E, S T Behmer (2010) Colony level macronutrient regulation in ants: mechanisms, hoarding and associated costs. Animal Behaviour 79: 429-437.

41. Dussutour A, S J Simpson (2009) Communal nutrition in ants. Communal nutrition in ants 19(9): 740-744.

42. Chown S L, K J Gaston (1999) Exploring links between physiology and ecology at macro-scales: the role of respiratory metabolism in insects. Biological Reviews 74(1): 87-120.

43. Canepuccia A D, Hidalgo F, Farina J L, Cuezzo F, O O Iribarne (2016) Environmental harshness decreases ant $\beta$-Diversity between salt marsh and neighboring upland environments. Wetlands 36: 667-680.

44. Markó B Kiss K, L Gallé (2004) Mosaic structure of ant communities (Hymenoptera: Formicidae) in Eastern Carpathian marshes: regional versus local scales. Acta Zoologica Scientiarum Hungaricae 50: 77-95.

This work is licensed under Creative

Commons Attribution 4.0 Licens

DOI: 10.19080/OFOAJ.2020.12.555838

\section{Your next submission with Juniper Publishers} will reach you the below assets

- Quality Editorial service

- Swift Peer Review

- Reprints availability

- E-prints Service

- Manuscript Podcast for convenient understanding

- Global attainment for your research

- Manuscript accessibility in different formats ( Pdf, E-pub, Full Text, Audio)

- Unceasing customer service

Track the below URL for one-step submission https://juniperpublishers.com/online-submission.php 